\title{
Brugbouer tussen generasies: Koos Roets se samewerkingsnetwerk in die Afrikaanse filmbedryf
}

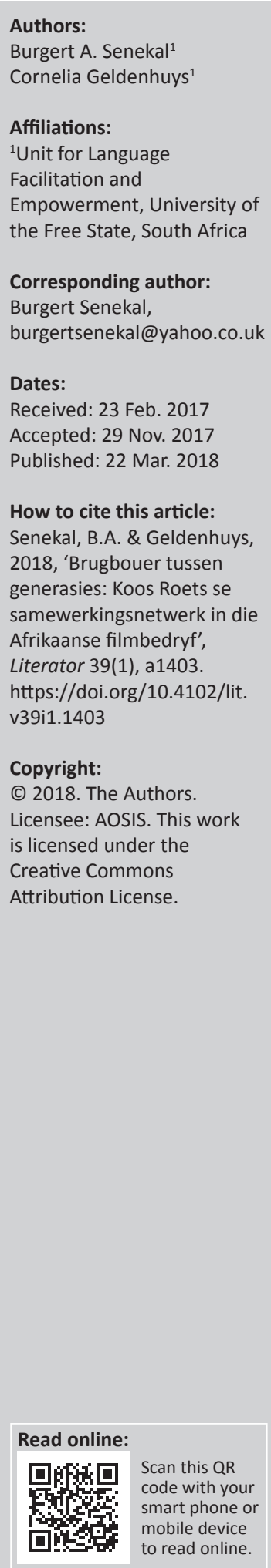

Bridge builder between generations: Koos Roets's cooperation network in the Afrikaans film industry. Koos Roets's contribution to the Afrikaans film industry is widely recognised. Nevertheless, very little has been published specifically about his role in the Afrikaans film industry, although many studies exist about his collaborators such as Jans Rautenbach and Katinka Heyns. This article investigates Roets's collaboration network by means of a network analysis, and identifies the persons with whom he collaborated the most, indicating his varied roles on different films. It is also indicated that he not only is and was an important role-player in his own right in this industry, but has also collaborated with many other important roleplayers in the Afrikaans film industry. He has contributed to Afrikaans films in collaboration with more than a 1000 persons throughout his career of nearly six decades. The directors, producers, sound operators, actors and crew with whom he has collaborated the most are highlighted, and the films on which they worked together are mentioned.

\section{Inleiding}

Botha (2015) noem Koos Roets een van die voorste kinematograwe in Suid-Afrika. Met vele toekennings (bv. vier Artes-toekennings, twee Rapport-Oscars, drie ATKV-toekennings, vier Star Tonight-toekennings asook die Stephen Farrell Lifetime Achievement Award vir kinematografie [https://af.wikipedia.org/wiki/Koos_Roets]) en erkennings van filmhistorici en -kritici (bv. Botha \& Van Aswegen 1991; Van Nierop 2016) is dit duidelik dat Roets se bydrae tot die Afrikaanse filmbedryf hoog aangeslaan word. De Swardt (2017) noem dat Roets se werk al 35 keer vir toekennings benoem is, waarvan hy 33 gewen het. Sommige van Roets se films, byvoorbeeld Faan se trein (2014) en ' $n$ Pawpaw vir my darling (2016), word as hoogtepunte in die geskiedenis van die Afrikaanse filmbedryf beskou en is baie positief deur filmkritici ontvang (kyk bv. Lombaard 2014; Pople 2016; Van Nierop 2016:336, 376). Dit impliseer dat hy 'n belangrike bydrae tot die skep van hoë kwaliteit films in Afrikaans gelewer het. Nie al sy films is ewe goed ontvang nie en Van Nierop (2016:242) is byvoorbeeld verdoemend wanneer hy skryf dat Kaalgat tussen die daisies (1997) 'n 'absolute laagtepunt' van die Afrikaanse filmbedryf was wat hom die Afrikaanse film 'laat afskryf' het. In die geheel gesien, het Roets egter aan 'n groot aantal films saamgewerk wat van die hoogtepunte in die geskiedenis van die Afrikaanse filmbedryf verteenwoordig.

Botha en Van Aswegen (1991:73) noem 'n paar rolprentvervaardigers wat die Suid-Afrikaanse filmbedryf gedurende 1960 tot 1980 oorheers het, insluitende Elmo de Witt, Dirk de Villiers, Bertrand Retief, Franz Marx, Koos Roets, Daan Retief, Ivan Hall, Manie van Rensburg, Jans Rautenbach, Emil Nofal, Jan Scholtz, Tommie Meyer, Jamie Uys en Ross Devenish. Nie alleen verskyn Roets se naam op hulle lys nie, maar deur sy bykans 60 jaar lange loopbaan in die Afrikaanse filmbedryf het Roets ook saam met van die belangrikste persone in hierdie bedryf gewerk, onder andere Elmo de Witt, Pierre de Wet, Katinka Heyns, Jans Rautenbach, Dirk de Villiers, Franz Marx, Jamie Uys en Emil Nofal. Hierdie samewerking is 'n sleutel tot die ontwikkeling van die Afrikaanse filmbedryf omdat mense uiteraard vaardighede by mekaar leer. Van Nierop (1999) skryf byvoorbeeld ten opsigte van waar Katinka Heyns haar vaardighede geleer het:

Sedert As ons twee eers getroud is en Die arme Marat op die verhoog, of in die rolprente van Jans Rautenbach soos Pappa Lap, Jannie Totsiens en Eendag op ' $n$ reëndag, het sy by van Suid-Afrika se beste pionierregisseurs begin leer. Koos Roets het haar van kamerawerk geleer, terwyl sy by Emil Nofal gesien het hoe sake, ook as vervaardiger, gedoen moet word. Jans Rautenbach het haar die kans gegee om as produksiebestuurder, stelinkleder, redigeerder en hulpregisseur op te tree. (bl. 3) 
Aansluitend by Van Nierop skryf Botha (2016) oor Jans Rautenbach:

Talle individue in die rolprentbedryf is deur Rautenbach beïnvloed en het hul eerste leerskool in die bedryf by hom ontvang: Katinka Heyns, Koos Roets, Regardt van den Bergh, Jana Cilliers en baie ander.

Omdat mense vaardighede by mekaar leer, is dit juis van waarde om ondersoek in te stel na wie saam met wie in die filmbedryf gewerk het. Let ook daarop dat sowel Botha (2016) as Van Nierop (1999) telkens Roets se naam noem wanneer van die voorste filmmakers ter sprake is. Dit beklemtoon hoe belangrik Roets se samewerkingsnetwerke in hierdie bedryf is.

Ten spyte van die feit dat Roets se bydrae tot die ontwikkeling van die Afrikaanse filmbedryf wel erken word, is daar egter nog min oor hom spesifiek gepubliseer. Alhoewel daar verskeie studies van ander belangrike rolspelers in die Afrikaanse filmbedryf bestaan soos Katinka Heyns (Botha 2015; Marx 2014; Nel 2003), Jamie Uys (Senekal \& Stemmet 2014; Stemmet 2015), Pierre de Wet (Senekal 2014a) en Jans Rautenbach (Botha 2006; Jansen van Vuuren 2016), is daar nog nie'n studie oor Koos Roets self onderneem nie. Selfs Van Nierop (2016) wat groot dele oor Pierre de Wet, Al Debbo, Jans Rautenbach en Katinka Heyns skryf, skryf min oor Roets.

Die huidige studie ondersoek Roets se samewerkings in die Afrikaanse filmbedryf vanuit 'n kwantitatiewe oogpunt deur sy samewerkingsnetwerk te ontleed. Die oogmerk is om te bepaal saam met wie hy die meeste gewerk het, maar ook om ondersoek in te stel hoe sy samewerkingsnetwerk deur sy loopbaan verander het. Vir hierdie doel word 'n groot datastel oor die Afrikaanse filmbedryf met behulp van 'n netwerkontleding verken. Hierdie datastel neem 28372 bydraes tot 412 Afrikaanse films wat oor die afgelope 100 jaar vrygestel is, in ag.

\section{Die datastel}

Die outeurs het data vir die huidige studie vanaf die krediete van Afrikaanse films saamgestel, met inagneming van bykans elke vollengte Afrikaanse speelfilm wat tussen 1916 en 2016 vrygestel is. Dokumentêre en kortfilms is met ander woorde nie hierby ingesluit nie en ook nie Engelse films nie (alhoewel Roets ook tot Engelse films soos The angel, the bicycle and the Chinaman's finger in 1992 bygedra het en ook in Brittanje en Australië gewerk het). Die samewerkings wat hier ondersoek word, sluit gevolglik ook nie Roets se samewerking in met persone soos Irvan Hillier, Dennis Coop, Ray Sturgess en Freddy Young nie-hierdie persone word wel deur De Swardt (2017) genoem. Die artikel ondersoek met ander woorde Roets se samewerkingsnetwerk in die Afrikaanse filmbedryf vanaf 1916 tot 2016. Elke persoon wat in die krediete van 'n Afrikaanse film genoem is, se naam is op 'n databasis aangebring sowel as die bydrae wat daardie persoon gelewer het (bv. as regisseur of akteur). Daar is nie slegs belangrike rolspelerkategorieë soos akteurs en regisseurs ingesluit nie, maar alle bydraes volgens die krediete van daardie film, aangesien die kleiner bydraes ook van waarde is vir 'n studie van die Afrikaanse filmbedryf. Dit is veral vir die huidige studie belangrik, omdat Roets se loopbaan as 'n kameraassistent begin het. In totaal bestaan die databasis uit 28372 bydraes tot 412 Afrikaanse films deur 15112 mense.

\section{Koos Roets se loopbaan in die Afrikaanse filmbedryf}

Koos Roets is een van die persone wat die langste en die produktiefste loopbane in die Afrikaanse filmbedryf gehad het. Deur sy 55 jaar lange loopbaan in die Afrikaanse filmbedryf (tot 2016) het hy tot 33 Afrikaanse films bygedra, meestal gekrediteer in die rolle van regisseur, kameraman, fotograaf en kinematograaf. Hy debuteer as kamera-assistent met die film Lord Oom Piet (1962) wat deur Jamie Uys geregisseer, geskryf en vervaardig is. Die volgende jaar werk hy as kamera-assistent aan die film Kimberley Jim (1963) wat deur Emil Nofal geskryf, geregisseer en vervaardig is, met Ivan Hall as produksiebestuurder. Ses jaar later werk hy weer as kamera-assistent - hierdie keer aan die film Danie Bosman (1969) wat deur Elmo de Witt geregisseer is. In dieselfde jaar doen hy die kinematografie vir Die geheim van Nantes (1969) wat deur Dirk de Villiers geregisseer is. Vanaf 1969 is hy bykans elke jaar by 'n Afrikaanse film betrokke en hy debuteer in 1971 as regisseur met die film Erfgenaam. Hy regisseer tot die einde van 201612 Afrikaanse films, naamlik Erfgenaam (1971), Vlug van die seemeeu (1972), Die sersant en die Tiger Moth (1973), Babbelkous en bruidegom (1974), Daar kom tant Alie (1976), Kootjie Emmer (1977), Die groen faktor (1984), Wie laaste lag (1986), Nag van die negentiende (1991), Kaalgat tussen die daisies (1997), Faan se trein (2014) en 'n Pawpaw vir my darling (2016). Let daarop dat Hoender met die rooi skoene eers in 2017 vrygestel is. Benewens sy bydraes as regisseur doen hy ook die kinematografie van films soos Pikkie (1972), Siener in die suburbs (1973), Somer (1975), Springbok (1976), Dit was aand en dit was more (1977), Lag met Wena (1977) en Nicolene (1978). Hy doen ook die fotografie van films soos Jannie totsiens (1970), Pappalap (1971), Eendag op 'n rë̈ndag (1975), Liefste Madelein (1976), Paljas (1998) en Die wonderwerker (2012). Figuur 1 verskaf ' $n$ oorsig oor sy loopbaan (sy rolle is aangedui soos dit in die krediete van films verskyn het).

Soos regs in Figuur 1 gesien kan word, het hy tydens die 1970s wat die hoogbloei van die Afrikaanse filmbedryf was, tot die meeste Afrikaanse films 'n bydrae gelewer. In hierdie dekade dra hy by tot 20 Afrikaanse films. Die groot gapings, veral tussen 1998 en 2012, is omdat daar baie min Afrikaanse films in hierdie tyd verskyn het. In hierdie tydperk was Roets ook meer binne die televisiebedryf aktief. Sedert 2010 het die aantal Afrikaanse films wat jaarliks vrygestel word, skerp toegeneem en Roets het weer 'n aktiewe rolspeler in hierdie bedryf geword. Hierdie is 'n belangrike faset van Roets se loopbaan wat later in meer besonderhede bespreek word: hy behoort nie soos Pierre de Wet of Jamie Uys slegs tot 'n ouer generasie nie, maar hy bou ' $n$ brug (ten opsigte van die mense saam met wie hy gewerk het) tussen die ouer generasie en die nuwe oplewing in die Afrikaanse filmbedryf. Links in 


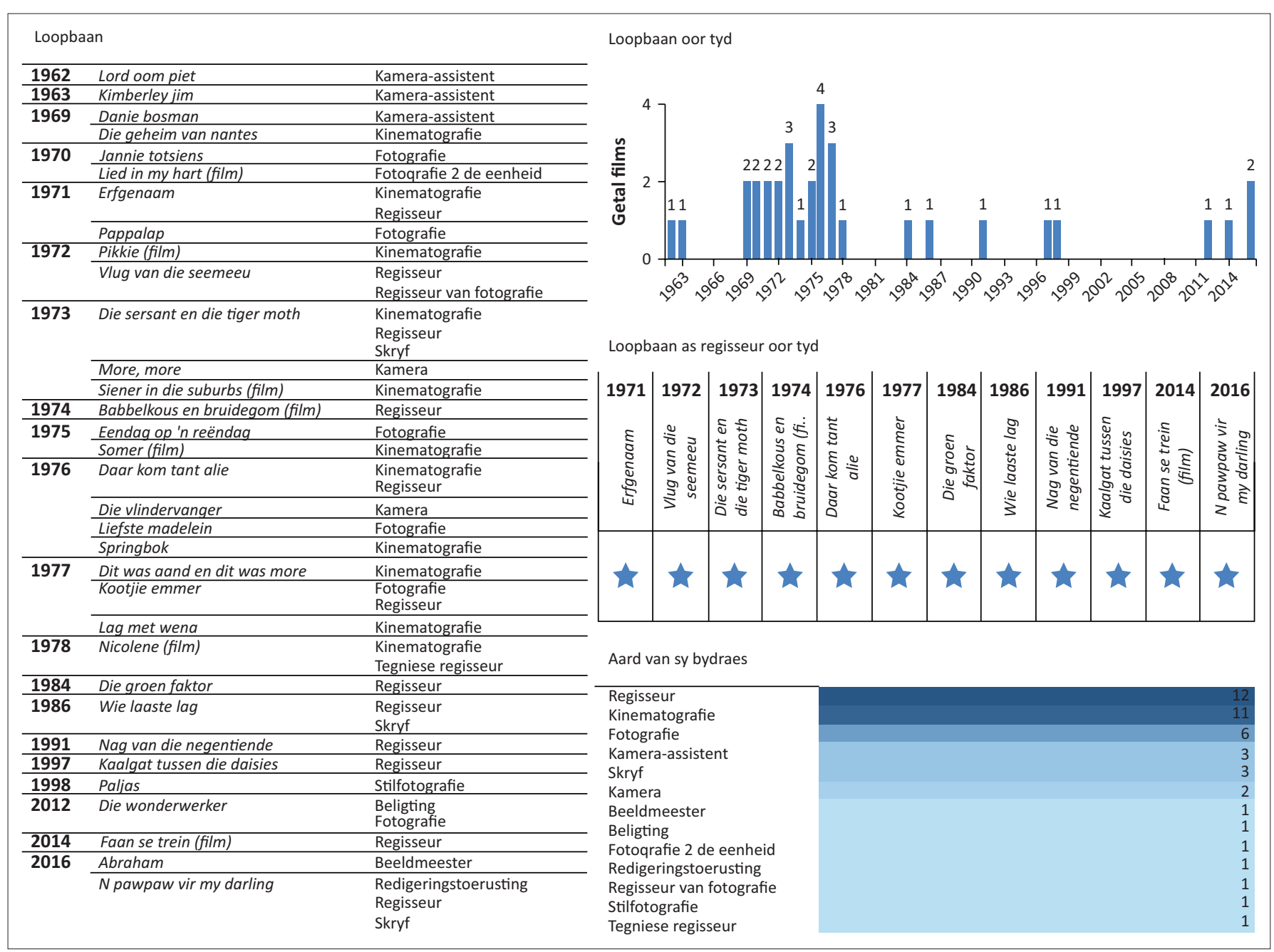

FIGUUR 1: 'n Oorsig oor Koos Roets se loopbaan.

Figuur 1, kan 'n lys van die films waartoe hy 'n bydrae gelewer het in chronologiese volgorde gesien word sowel as die aard van sy bydrae. In die middel regs, is 'n samevatting van sy loopbaan as regisseur (tot die einde van 2016) en regs onder, word aangedui in watter rol hy die meeste tot films bygedra het - met 12 krediete as regisseur, 11 as kinematograaf, 6 vir fotografie en 3 as draaiboekskrywer.

Die belangrike aspek van Roets se loopbaan wat in die huidige studie ondersoek word, is egter saam met wie hy deur sy loopbaan gewerk het. Hierdie aspek word in die res van die artikel bespreek.

\section{'n Breë oorsig oor Koos Roets se samewerkingsnetwerk}

Kurt Lewin het die sosiale omgewing as 'n veld gekonseptualiseer wat later 'n invloed op Pierre Bourdieu se veldteorie sowel as die sosiale vertakking van die netwerkteorie, sosiale-netwerk-analise (SNA), sou uitoefen (kyk onderskeidelik na DiMaggio 1979:1462; en Prell 2012:24). Die term veld verwys in hierdie geval na 'both the totality of actors and organizations involved in an arena of social or cultural production and the dynamic relationships among them' (DiMaggio 1979:1462-1463). Dit sluit duidelik ook 'n filmbedryf in waar 'n verskeidenheid rolspelers se dinamiese verhoudings die bedryf laat voortbestaan. Lewin (1939) skryf oor die sosiale veld:

Whether or not a certain type of behavior occurs depends not on the presence or absence of one fact, or of a number of facts as viewed in isolation but upon the constellation (structure and forces) of the specific field as a whole. The 'meaning' of the single fact depends upon its position in the field; or, to say the same in more dynamical terms, the different parts of a field are mutually interdependent. (bl. 889)

Die werke van Bourdieu is meer bekend as dié van Lewin wanneer 'n kultuurstudie ter sprake is, ook waar dit binne die Afrikaanse literatuurstudie neerslag gevind het en waarvan Jacobs (2016) 'n onlangse voorbeeld is. Bourdieu se veldteorie word ook binne die filmstudie toegepas, byvoorbeeld deur Baumann (2001; 2002), Allen en Lincoln (2004), en Heise en Tudor (2007). Soos Lewin erken Bourdieu (1971:161) ook die interafhanklikheid tussen entiteite binne die sosiale veld: 'The intellectual field, [...] cannot be reduced to a simple aggregate of isolated agents or to the sum of elements merely juxtaposed' (kyk ook Bourdieu 1983:312). Lewin verteenwoordig met ander woorde ' $n$ aanknopingspunt tussen die intellektuele geskiedenis van die veld- en netwerkteorieë en albei teorieë is vantevore vir die ondersoek van filmbedrywe aangewend. 
Soos in die geval met die veldteorie val die klem binne die netwerkteorie op die verhoudings tussen entiteite (nodusse) binne 'n sisteem of netwerk. Volgens Costa et al. (2011) het hierdie verhoudings ook vanuit die perspektief van die netwerkteorie 'n impak op die ontwikkeling van 'n kultuur:

Since ancient times, the way individuals establish relations among themselves has been crucial to guide the cultural and economic evolution of society. Hidden and clear relationships have always defined different social, diplomatic, commercial and even cultural networks. (bl. 335)

'n Groot hoeveelheid navorsing is onlangs onderneem wat professionele samewerkingsnetwerke vanuit 'n netwerkteoretiese oogpunt ondersoek, insluitende netwerke van maatskappydirekteure (Davis, Yoo \& Baker 2003), medeouteurskappe (Ding 2011), sportspanne (Guimera et al. 2005), samewerkingsnetwerke in gesondheidsorg (Manuel et al. 2011), musiek (Giannetti 2016) en onderwysers (Van Staden 2016). 'n Gunsteling studie-objek binne die toepassings van die netwerkteorie is filmakteurnetwerke. Dit is reeds vir bykans twee dekades binne die netwerkteorie bestudeer (Barabási, Albert \& Jeong 1999; Gallos et al. 2013; Guillaume \& Latapy 2004; Phalen, Ksiazek \& Garber 2016; Watts \& Strogatz 1998; Zhang et al. 2006). Ook die Afrikaanse filmbedryf is al vanuit hierdie invalshoek bestudeer (Senekal 2014a; 2015a; 2015b; Senekal \& Stemmet 2014).

Samewerkingsnetwerke word gereeld as tweeledige netwerke bestudeer, waar die netwerk uit twee soorte nodusse bestaan, byvoorbeeld maatskappye en direkteurs, outeurs en publikasies, of akteurs en films (Guillaume \& Latapy 2004). Tweeledige netwerke is ryk aan inligting en ontledingsmoontlikhede: die netwerk kan as 'n tweeledige netwerk bestudeer word, maar kan ook na 'n enkelledige netwerk omgeskakel word waar slegs een soort nodus aangetref word. In 'n filmakteurnetwerk kan daar byvoorbeeld in die tweeledige weergawe aangedui word dat twee akteurs elk 'n rol in 'n film vertolk, maar in die enkelledige weergawe word 'n direkte skakel tussen die akteurs aangedui om aan te toon dat hulle saam rolle in 'n film vertolk het (Senekal 2015b:49-50). Boonop kan die aantal kere wat twee akteurs saam in 'n film gespeel het, aangedui word deur ' $n$ gewig aan 'n skakel toe te ken wat die moontlikheid skep om die gewig van skakels in te reken om 'n netwerk verder te verken.

Laasgenoemde metode is in die huidige artikel gebruik om nie alleen die persone te identifiseer wat saam met Koos Roets gewerk het nie, maar ook die aantal kere wat mense saam met hom aan 'n film gewerk het. Boonop is daar tussen verskillende soorte samewerkings onderskei wat dit moontlik maak om ondersoek in te stel saam met watter regisseurs, akteurs, ensovoorts hy die meeste gewerk het. Verder word die datums aangedui wanneer die films vrygestel is om dit moontlik te maak om spesifieke tydperke te ondersoek soos in die volgende afdeling onderneem word.

Indien 'n mens die Afrikaanse filmbedryf vanaf 1916 tot 2016 as 'n tweeledige netwerk met behulp van bogenoemde datastel voorstel, is daar 15523 nodes (mense en films) en

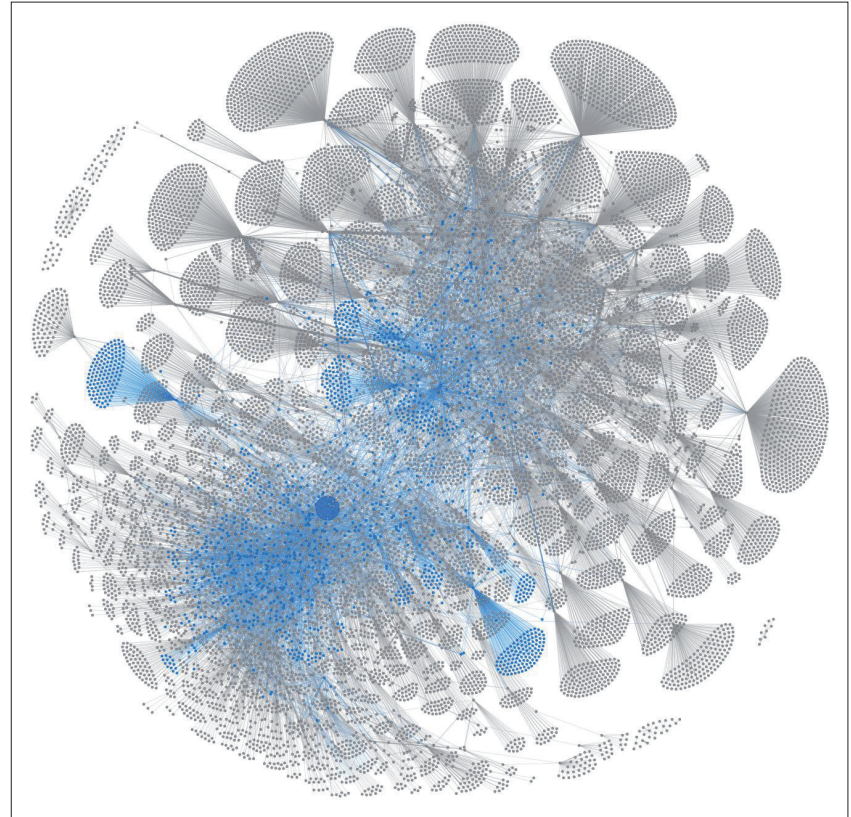

FIGUUR 2: Koos Roets in die Afrikaanse filmbedryf 1916-2016.

24720 skakels (bydraes) in die netwerk. Figuur 2 dui die Afrikaanse filmbedryf vanaf 1916 tot 2016 aan as 'n tweeledige netwerk, met films en mense as nodusse en mense se bydraes tot films as skakels. Koos Roets word met die grootste nodus aangedui. Die films waaraan hy gewerk het sowel as mense wat saam met hom gewerk het, word in blou aangedui, terwyl films en mense waarmee hy geen direkte skakel gehad het nie, in grys aangedui word. Die kraggebaseerde uitlegalgoritme van Fruchterman en Reingold (1991) is vir hierdie visualisering gebruik.

Figuur 2 dui 'n aantal betekenisvolle aspekte omtrent Roets se samewerkingsverhoudings aan. Daar kan duidelik gesien word dat hy saam met 'n groot aantal mense gewerk het wat hieronder uitgelig en later in meer besonderhede bespreek word. Die films waaraan hy gewerk het en die mense met wie hy saamgewerk het, maak $11.48 \%$ van die nodusse en $22.55 \%$ van die skakels in die hele filmbedryf uit. Dit dui reeds daarop dat hy saam met 'n groot persentasie van die mense gewerk het wat by die Afrikaanse filmbedryf betrokke was. In Pierre de Wet se geval het hy skakels met 3.83\% van die nodusse in Figuur 2, Katinka Heyns met 6.11\%, Jamie Uys met 5.02\% en Jans Rautenbach met 5.26\%. Dit beteken dat Roets meer skakels as hierdie ander groot filmmakers gebou het. Meer skakels beteken in hierdie geval die potensiaal om inligting makliker oor te dra, om meer mense direk te bereik en om by ' $n$ groter aantal mense te leer.

Dit is verder opvallend dat daar veral twee groot groepe in die Afrikaanse filmbedryf bestaan, met die een links onder en die ander regs bo in Figuur 2 (daar loop as 't ware 'n diagonale lyn van links bo na regs onder deur die netwerk wat die twee groepe skei). Hierdie twee groepe bestaan hoofsaaklik uit ouer en nuwer films en die mense wat daarop gewerk het; min of meer films van voor en na $2000 .{ }^{1}$

1.Let daarop dat hierdie onderskeid net ten opsigte van mense en nie ten opsigte van tematiese ontwikkeling getref word nie. 
Uit Figuur 2 kan Roets gesien word as 'n figuur wat hierdie twee groepe verbind deur 'n groot aantal skakels met mense van albei groepe te hê. Dit lig hom verder uit as iemand wat 'n uitsonderlike bydrae tot die Afrikaanse filmbedryf gelewer het: hy is deel van die ouer generasie (links onder in Figuur 2) wat die Afrikaanse filmbedryf help vestig het, maar ook by nuwe films betrokke is, en wat die bedryf tans lewendig hou (regs bo in Figuur 2).

Dit blyk duidelik dat Roets sowel as vele van sy medewerkers in die kern van die Afrikaanse filmbedryf aangetref word. In Senekal en Stemmet (2014:12) en Senekal (2014b) word aangedui dat kraggebaseerde uitleg-algoritmes, byvoorbeeld dié van Fruchterman en Reingold (1991), belangrike rolspelers binne die kern van 'n netwerk posisioneer as gevolg van hulle skakels met ander belangrike rolspelers (vir voorbeelde van kraggebaseerde uitleg-algoritmes wat op verskeie soorte netwerke toegepas is, kyk Senekal 2014b.). Roets sowel as 'n groot aantal van sy medewerkers kan dus in Figuur 2 gesien word as sentrale rolspelers binne die Afrikaanse filmbedryf oor die afgelope eeu. Hulle verteenwoordig meer gevestigde en invloedryke rolspelers. Let ook daarop dat talle nodusse op die periferie ook blou gekleur is: nodusse op die periferie verteenwoordig gereeld nuwelinge in sosiale netwerke wat aandui dat 'n groot hoeveelheid nuwelinge ook saam met Roets gewerk het.
Neem 'n mens egter slegs die persone in ag wat saam met Koos Roets gewerk het (in plaas van sy films en medewerkers), met ander woorde 'n enkelledige projeksie van sy samewerkingsnetwerk, is daar 1357 nodes (mense) en 62763 skakels (samewerkingsverhoudings) in Roets se samewerkingsnetwerk. Dit beteken dat Roets deur sy loopbaan saam met 1356 (hyself uitgesluit) persone aan films gewerk het en dat daar 62763 onderlinge samewerkingsverhoudings in hierdie deel van die Afrikaanse filmbedryf as netwerk bestaan. In Senekal (2015a) is aangedui dat Roets gereeld saam met dieselfde persone gewerk het en Figuur 3 dui hierdie persone aan.

In Figuur 3 kan gesien word dat Roets oor die algemeen die meeste saam met Sias Odendaal gewerk het (8 films), gevolg deur Don Leonard, Franz Marx, Jacques Loots, Katinka Heyns, Paul Thompson, Tobie Cronjé, Tommie Meyer en Willie du Toit (7 films elk). Die draaiboekskrywers saam met wie hy die meeste gewerk het, is Franz Marx (3 films), André P. Brink, Chris Barnard, Emil Nofal, Jan Scholtz, Jans Rautenbach en P.G. du Plessis (2 films elk). Die akteurs saam met wie hy die meeste saamgewerk het, sluit baie van die groot name in die geskiedenis van die Afrikaanse filmbedryf in, naamlik Don Leonard en Jacques Loots (7 films elk), Sann de Lange, Tobie Cronjé, Wena Naudé (6 films elk), Jan Bruyns, Katinka Heyns, Marga van

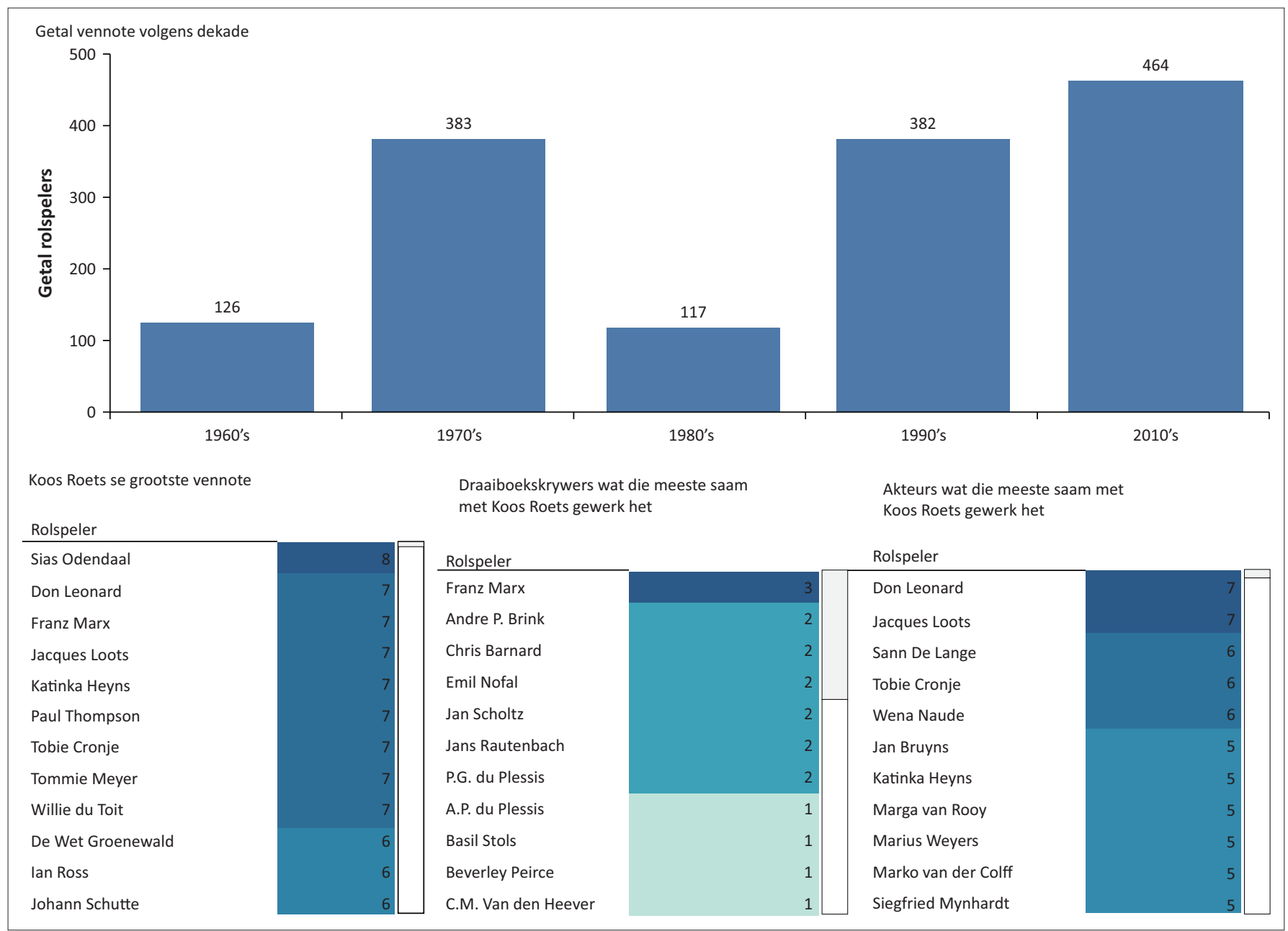

FIGUUR 3: Koos Roets se vernaamste vennote. 
Rooy, Marius Weyers, Marko van der Colff en Siegfried Mynhardt (5 films elk).

Die mense met wie Roets die meeste saamgewerk het, hetsy vervaardigers, regisseurs, akteurs of draaiboekskrywers, is duidelik bekende persone in die Afrikaanse filmbedryf. Hulle is van die gevestigde individue wat binne die kern van die Afrikaanse filmbedryf aangetref word en heelwat van die persone wat deur Botha en Van Aswegen (1991) as dominante persone in die geskiedenis van die Suid-Afrikaanse filmbedryf aangedui word. In Figuur 3 kan gesien word dat:

- Roets 'n lang en produktiewe loopbaan in die Afrikaanse filmbedryf gehad het (soos in detail in Figuur 1 aangedui is);

- hy binne die kern van die Afrikaanse filmbedryf aangetref word en saam met ander sentrale figure gewerk het (soos op ' $n$ ander wyse in Figuur 2 aangedui is);

- wanneer ondersoek ingestel word saam met watter individue hy die meeste gewerk het, kan gesien word dat hy deur sy loopbaan gereeld in kontak gekom het met van die mense wat sleutelrolle in die ontwikkeling van die Afrikaanse filmbedryf gespeel het.

Let ook daarop dat die persone wat in die vorige paragraaf uitgelig is, tot twee generasies behoort: Sann de Lange, Wena Naudé en Don Leonard behoort tot 'n ouer generasie, terwyl Marius Weyers en Marko van der Colff eers later by die Afrikaanse filmbedryf betrokke geraak het.

Roets het uiteraard in verskillende tydperke en aan verskillende films saam met verskillende mense gewerk en die volgende afdeling bespreek die ontwikkeling van sy samewerkingsnetwerk in meer besonderhede oor die bykans ses dekades wat hy by die Afrikaanse filmbedryf betrokke was.

\section{Die ontwikkeling van Koos Roets se samewerkingsnetwerk}

Roets se loopbaan begin as kamera-assistent by Lord Oom Piet $^{2}$ wat deur Jamie Uys geregisseer, vervaardig en geskryf is (saam met Emil Nofal). Jamie Uys was op daardie stadium reeds 'n gevestigde filmmaker in Suid-Afrika en Lord Oom Piet was reeds die 13e film waarby hy betrokke was. (Uys sou uiteindelik een van die produktiefste en suksesvolste filmmakers in die Afrikaanse filmbedryf word; kyk Stemmet 2015). Met Lord Oom Piet werk Roets die eerste keer aan 'n film saam met Emil Nofal; later sou Roets Die groen faktor regisseer wat ook deur Nofal geskryf is. Ivan Hall werk as produksiebestuurder aan Lord Oom Piet, asook later weer saam met Roets aan Kimberley Jim en Lied in my hart. Met Lord Oom Piet werk Roets ook die eerste keer saam met die aktrise wat in die meeste Afrikaanse films gespeel het deur hierdie bedryf se eeulange geskiedenis, naamlik Sann de Lange. Deur haar 48 jaar lange loopbaan het sy rolle in 44 Afrikaanse films vertolk - meer as enige ander akteur (Wena Naudé het 37 rolle in films vertolk - die tweede meeste). De Lange sou

2.Roets kom nie in die krediete van Lord Oom Piet voor nie, maar De Swardt (2017) noem dat Roets se loopbaan hier begin het. ook rolle vertolk in vele ander Afrikaanse films waarby Roets betrokke was, insluitend Lied in my hart, Vlug van die seemeeu, Die sersant en die Tiger Moth, Liefste Madelein en Lag met Wena.

In die volgende jaar werk Roets as kamera-assistent aan Kimberley Jim wat deur Emil Nofal geskryf, vervaardig en geregisseer word. Jans Rautenbach tree as akteur en assistentregisseur in Kimberley Jim op. Hiermee ontstaan 'n lang samewerkingsverhouding wat films soos Jannie totsiens, Pappalap, Eendag op 'n rë̈ndag en Abraham sou insluit. Later sou Roets aanvoer dat hy alles wat hy weet by Rautenbach geleer het (Jansen van Vuuren 2016). Don Leonard vertolk ook ' $n$ rol as akteur in Kimberley Jim en Leonard sou die akteur word wat in die meeste films gespeel het waarby Roets betrokke was, naamlik Danie Bosman, Jannie Totsiens, Erfgenaam, Vlug van die seemeeu, Die sersant en die Tiger Moth en More, more.

Danie Bosman wat deur Elmo de Witt geregisseer word, tree Roets weereens as kamera-assistent op. Saam met Die geheim van Nantes wat deur Elmo de Witt vervaardig word, is hierdie die eerste keer dat Roets saam met De Witt werk. Later sou hulle ook aan Lied in my hart en More, more saamwerk. Sias Odendaal behartig die redigering van hierdie film en Roets sou uiteindelik aan agt Afrikaanse films saam met Sias Odendaal werk wat hom die persoon maak saam met wie Roets die meeste sou werk: Die geheim van Nantes, Lied in my hart, Pikkie, More, more, Somer, Daar kom tant Alie en Springbok. Franz Marx vertolk 'n rol as akteur in Danie Bosman en sou ook betrokke wees by sewe Afrikaanse films saam met Roets, naamlik Lied in my hart, Pikkie, Die vlindervanger, Liefste Madelein, Dit was aand en dit was more en Nicolene. Roets werk ook die eerste keer saam met Willie du Toit aan Danie Bosman en Die geheim van Nantes. Du Toit sou later die klankversorger word wat die meeste saam met Roets gewerk het en saam met Roets tot Jannie totsiens, Lied in my hart, Erfgenaam, Pikkie en Vlug van die seemeeu bydra. Met Danie Bosman en Die geheim van Nantes werk Roets ook die eerste keer saam met Philip Markgraaff wat een van die produksiebestuurders is waarmee Roets die meeste sou saamwerk. Markgraaff het byvoorbeeld as produksiebestuurder opgetree in films soos Lied in my hart, Môre, môre, Die vlindervanger en Dit was aand en dit was môre.

Vir Die geheim van Nantes, waar Sias Odendaal die produksiebestuur en Dirk de Villiers die regie behartig, tree Roets as kinematograaf op. Roets werk vir die eerste keer saam aan hierdie film met die vervaardiger, Tommie Meyer, met wie hy die meeste sou saamwerk. Meyer sou ook Lied in my hart, Pikkie, Babbelkous en bruidegom, Somer en Daar kom tant Alie vervaardig, en Springbok regisseer. Later sou Dirk de Villiers ook 'n rol in Kaalgat tussen die daisies vertolk wat deur Roets geregisseer word.

In 1970 verskyn Jannie totsiens wat deur Jans Rautenbach geregisseer word en waar Roets die fotografie behartig. Jacques Loots vertolk ' $n$ rol in hierdie film en naas Don Leonard sou hy die akteur word wat rolle vertolk in die 
meeste films waarby Roets betrokke was, te wete Lied in my hart, Die sersant en die Tiger Moth, Somer, Kootjie Emmer, Die groen faktor en Nag van die negentiende. Roets het ook nou vir die eerste keer saam met Katinka Heyns gewerk wat ' $n$ rol as akteur vertolk het. Botha (2015) noem Roets 'n belangrike kreatiewe krag in Heyns se oeuvre en Roets en Heyns se samewerking sou oor 42 jaar strek. Dit sou samewerking aan films soos Pappalap, Die Sersant en die Tiger Moth, Babbelkous en bruidegom, Eendag op 'n reëndag, Paljas en Die wonderwerker insluit. Roets trou in 1971 met Heyns wat na hulle egskeiding in 1978 uiteindelik met Chris Barnard ('n ander belangrike samewerker van Roets sedert Pikkie) sou trou.

Vir Lied in my hart wat deur Ivan Hall geregisseer en deur Elmo de Witt en Tommie Meyer vervaardig word, is Roets deel van die tweede eenheid se fotografie. Sias Odendaal maak deel uit van die animasiespan en doen die titelontwerp; Franz Marx doen die verklanking, en akteurs soos Gé Korsten, Min Shaw, Patrick Mynhardt, Siegfried Mynhardt, Sann de Lange en Pieter Hauptfleisch vertolk rolle.

Erfgenaam is Roets se debuut as regisseur. Akteurs soos Don Leonard en Koos Meyer vertolk rolle, die produksiebestuur word deur De Wet Groenewald behartig en die film word deur Dawie Fourie vervaardig. Laasgenoemde sou ook twee jaar later Siener in die suburbs vervaardig.

Jans Rautenbach en Koos Roets werk weereens saam aan Pappalap: Rautenbach as regisseur en Roets as fotograaf. Katinka Heyns vertolk ook ' $n$ rol in hierdie film en dit is die eerste keer dat Roets saam met Marga van Rooy werk wat 'n rol as aktrise in haar eerste Afrikaanse film vertolk en haar loopbaan in die Afrikaanse filmbedryf begin. Van Rooy en Roets sou ook aan Babbelkous en bruidegom, Eendag op 'n reëndag, Die groen faktor en 'n Pawpaw vir my darling saamwerk. Marga van Rooy wat in 2017 oorlede is, is een van die nuwer generasie akteurs by wie se loopbaan Roets met ander woorde van meet af aan betrokke was.

Vir Pikkie wat deur Sias Odendaal geregisseer word, doen Roets die kinematografie. Franz Marx behartig die drama-afrigting, De Wet Groenewald tree weereens as produksiebestuurder op en Tommie Meyer as vervaardiger. Chris Barnard behartig die vertaling en in die toekoms sou Roets en Barnard aan 'n paar films saamwerk. Barnard skryf Paljas, waar Roets die stilfotografie doen en Die wonderwerker, waar Roets die beligting en fotografie doen.

In 1972 volg Vlug van die seemeeu wat Roets regisseer. In hierdie film werk Roets die eerste keer saam met die tweede produktiefste aktrise (naas Sann de Lange) in die geskiedenis van die Afrikaanse filmbedryf: Wena Naudé. Sy sou ook in Die sersant en die Tiger Moth, Daar kom tant Alie, Die vlindervanger en Lag met Wena speel. Sann de Lange sowel as Pieter Fourie vertolk ook 'n rol in hierdie film. Roets sou later Fourie se drama, Faan se trein, regisseer.

In 1973 verskyn Die sersant en die Tiger Moth wat deur Roets geregisseer word met De Wet Groenewald as vervaardiger.
Aan hierdie film en die film Môre, môre, werk Roets vir die eerste keer saam met die akteur Tobie Cronjé, 'n samewerkingsverhouding wat tot op hede oor 43 jaar sou strek. Cronjé en Roets werk ook saam aan Babbelkous en bruidegom, Daar kom tant Alie, Kootjie Emmer, Lag met Wena en ' $n$ Pawpaw vir my darling. In hierdie film werk Roets vir die eerste keer saam met Marko van der Colff wat in die komende jare ook rolle sou vertolk in Babbelkous en bruidegom, Nag van die negentiende, Kaalgat tussen die daisies en Paljas. Sann de Lange en Wena Naudé vertolk weereens rolle as akteurs.

Roets behartig ook die kamera tydens die skiet van Môre, môre, waar Sias Odendaal as produksiebestuurder optree. Die film word deur Elmo de Witt geregisseer en Jan Scholtz skryf die draaiboek vir hierdie film. Aan hierdie film werk Roets vir die eerste keer saam met Bob Riley saam met wie hy later aan vyf films gewerk het. Riley doen die grimering, kontinuïteit en is deel van die kunsdepartement tydens die maak van Môre, môre, vertolk 'n rol as akteur in Babbelkous en bruidegom, behartig die grimering en kontinuïteit van Somer (en is ook die assistentregisseur), en vertolk 'n rol en is die assistentregisseur van Daar kom tant Alie en Springbok.

Ook in 1973 verskyn Siener in die suburbs wat deur Francois Swart geregisseer word en waartoe Roets as kinematograaf bydra. Aan hierdie film werk Roets vir die eerste keer saam met Marius Weyers wat 'n rol as akteur vertolk. Hulle sou later weer saam aan die films Daar kom tant Alie, Paljas, Die wonderwerker en Faan se trein werk. Weyers is een van die akteurs wat in die tweede helfte van die twintigste eeu tot die Afrikaanse filmbedryf toegetree het, maar wat tans een van Suid-Afrika se mees gerekende akteurs is. Ook hier funksioneer Roets as skakel tussen die ouer en die nuwer generasie in die Afrikaanse filmbedryf. Die film is 'n verwerking van 'n drama van P.G. du Plessis. Du Plessis en Roets sou ook later aan Nag van die negentiende wat Roets geregisseer het, saamwerk.

Babbelkous en bruidegom, geregisseer deur Roets met Tommie Meyer as vervaardiger, verskyn in die volgende jaar (1974). Bekende akteurs waarmee Roets vantevore saamgewerk het en weer rolle in hierdie film vertolk, sluit Katinka Heyns, Marga van Rooy, Marko van der Colff en Tobie Cronjé in.

Jans Rautenbach regisseer Eendag op 'n rëndag, waar Roets die fotografie doen. Paul Thompson tree in hierdie film as kamera-assistent op. Hy sou in verskeie latere films as kamera-assistent optree vir films waarby Roets betrokke was, insluitende Somer, Daar kom tant Alie, Die vlindervanger en Liefste Madelein. Thompson doen ook die kinematografie vir Lag met Wena en is 'n kamera-operateur vir Die wonderwerker. Bekende akteurs wat rolle in hierdie film vertolk, sluit Katinka Heyns, Grethe Fox en Regardt van den Bergh in. Musiek van Jacques Brel word vir die film gebruik.

In 1975 tree Roets as kinematograaf op vir Somer wat deur Sias Odendaal geregisseer word en deur C.M. van den Heever geskryf is (met 'n draaiboekverwerking deur André P. Brink). Roets werk deur sy loopbaan aan nog twee films waarby 
André P. Brink betrokke was, naamlik as regisseur vir Kootjie Emmer wat deur Brink geskryf is en as kinematograaf vir Nicolene, waar Brink die draaiboekaanpassing doen. Saam met Pieter Fourie, Chris Barnard, Jeanne Goosen, Verna Vels en P.G. du Plessis is Brink van die bekende Afrikaanse skrywers wat bydraes gelewer het tot films waarby Roets betrokke was.

Vir Daar kom tant Alie behartig Roets die regie en kinematografie. Sias Odendaal tree as medevervaardiger op en Tommie Meyer weereens as vervaardiger. Akteurs waarmee Roets reeds verskeie kere in die verlede saamgewerk het, byvoorbeeld Marius Weyers, Tobie Cronjé, Wena Naudé en Siegfried Mynhardt, vertolk ook rolle in hierdie film.

In 1976 verskyn Die vlindervanger, waar Roets die kamera behartig. Die filmteks word deur Franz Marx geskryf en geregisseer. Die klank word vir Die vlindervanger deur Ian Ross behartig wat die klankversorger is waarmee Roets die tweede meeste sou saamwerk (naas Willie du Toit): Ross doen ook die klank vir Liefste Madelein, Dit was aand en dit was môre, Kootjie Emmer, Lag met Wena (waar hy ook die kinematografie behartig) en Nicolene. Aan hierdie film werk Roets die eerste keer saam met Albie Venter wat die vervaardiger is met wie hy die tweede meeste sou saamwerk (naas Tommie Meyer). Venter was ook die vervaardiger van Liefste Madelein, Dit was aand en dit was môre, Kootjie Emmer en Nicolene.

Franz Marx skryf en regisseer ook Liefste Madelein waar Roets die fotografie behartig. Bekende akteurs wat rolle in hierdie film vertolk, sluit Sann de Lange, Wena Naude, Wilna Snyman en Trudie Taljaard in.

Vir Springbok wat deur Tommie Meyer geregisseer word, behartig Roets die kinematografie en Sias Odendaal die produksiebestuur. Die draaiboek word deur Jan Scholtz geskryf wat deur sy loopbaan tot 20 Afrikaanse films bygedra het waarvan hy 18 se draaiboeke geskryf en 10 geregisseer het.

Franz Marx skryf, regisseer en vertolk ook 'n rol in Dit was aand en dit was môre waar Roets die kinematografie behartig. Albie Venter wat ook films soos Kootjie Emmer en Nicolene vervaardig het, tree as vervaardiger op.

Kootjie Emmer verskyn in 1977, geregisseer deur Roets en vervaardig deur Albie Venter met André P. Brink wat die draaiboek skryf.

In dieselfde jaar verskyn Lag met Wena met Morné Coetzer as regisseur. Paul Thompson, saam met wie Roets die eerste keer op die stel van Eendag op 'n reëndag en Somer gewerk het, behartig die kinematografie saam met Roets en Ernest Kleynhans. Verna Vels skryf die draaiboek - sy is ook bekend vir haar Liewe Heksie-stories en haar rol as akteur in die televisiereeks Wielie Walie (1976).

Vir Nicolene tree Franz Marx as artistieke regisseur op met Marie du Toit as regisseur en Albie Venter as vervaardiger. André P. Brink doen weereens die draaiboekaanpassing en Pierre de Wet vertolk 'n rol as akteur.
Nadat Roets vir ses jaar nie by Afrikaanse films betrokke was nie, regisseer hy Die groen faktor in 1984. Die filmteks is deur Emil Nofal geskryf en deur Paul Raleigh vervaardig. Raleigh sou later een van die persone word wat by die meeste Afrikaanse films betrokke is - meestal verantwoordelik vir die voltooiingswaarborg, byvoorbeeld Uitvlucht (2016), Die ontwaking (2016), Abraham (2016), 'n Man soos my pa (2015), Dis ek, Anna (2015) en Ballade vir 'n enkeling (2015). Hierdie film verteenwoordig met ander woorde 'n belangrike brug tussen die ouer en nuwer Afrikaanse filmbedryf: Emil Nofal wat tot die ouer generasie behoort en Paul Raleigh wat 'n belangrike rol in nuwe Afrikaanse films speel, werk saam aan 'n film wat deur Roets geregisseer word.

Wie laaste lag verskyn twee jaar na Die groen faktor (1986). Aan hierdie film werk Roets die eerste keer saam met Willie Esterhuizen met wie hy ook later aan Kaalgat tussen die daisies (1997), Faan se trein (2014) en 'n Pawpaw vir my darling (2016) sou saamwerk. Esterhuizen is sedert Lipstiek dipstiek (1994) bekend vir sy komedies, waarin Roets nogmaals 'n aanknopingspunt tussen 'n ouer en nuwer generasie rolspelers in die Afrikaanse filmbedryf verteenwoordig. Die film word deur Philo Pieterse vervaardig wat ook films soos Boetie gaan border toe (1984), Boetie op maneuvers (1985), Orkney snork nie (1992), Orkney snork nie 2 (1993), Lipstiek dipstiek (1994), Platteland (2011) en Verskietende ster (2016) vervaardig.

Ses jaar later regisseer Roets Nag van die negentiende (1991), geskryf deur P.G. du Plessis. Aan hierdie film werk Roets die eerste keer saam met Dawid Minnaar wat ook later saam met Roets aan films soos Die wonderwerker (2012) en 'n Pawpaw vir my darling sou werk.

Kaalgat tussen die daisies (1997) is een van slegs twee Afrikaanse films wat in die tweede helfte van die negentigerjare verskyn (die ander is Paljas) en word ook deur Roets geregisseer. Bekende akteurs wat rolle in hierdie film vertolk, sluit Dirk de Villiers, Frank Opperman, Gys de Villiers, Marko van der Colff, Soli Philander, Tolla van der Merwe, Willie Esterhuizen en Zack du Plessis in. Soos reeds genoem, is die film egter nie goed ontvang nie.

Paljas verskyn in die volgende jaar. Dit word geregisseer en deur een van Roets se oudste vennote, Katinka Heyns, medevervaardig. Teen hierdie tyd staan sy eerder as regisseur as akteur bekend nie. Die draaiboek word deur Chris Barnard geskryf en Roets behartig die stilfotografie.

Na Paljas verdwyn Roets vir bykans 'n dekade en 'n half van die toneel van die Afrikaanse filmbedryf totdat hy weer tydens die onlangse oplewing in die Afrikaanse filmbedryf betrokke raak. In 2012 behartig hy die beligting en fotografie vir Katinka Heyns se Die wonderwerker (2012), met Dawid Minnaar in die hoofrol. Paul Thompson wat voorheen aan films soos Lag met Wena en Eendag op 'n reëndag saam met Roets gewerk het, is die kamera-operateur vir hierdie film en so verteenwoordig Roets weereens 'n brug tussen 'n ouer en nuwer generasie. 
Twee jaar later keer Roets terug as regisseur met Faan se trein (2014) wat sy eerste film as regisseur is sedert Kaalgat tussen die daisies. Volgens Van Nierop (2016:336) span hierdie film 'die kroon op sy werk oor die afgelope 50 jaar as kinematograaf, vervaardiger en regisseur'. Dit is ' $\mathrm{n}$ verfilming van Pieter Fourie se drama met Deon Lotz, Cobus Rossouw en Willie Esterhuizen in die hoofrolle - Roets het Fourie se Vlug van die seemeeu ook geregisseer.

Na 'n 32 jaar lange afwesigheid keer Jans Rautenbach ook in 2016 terug na die Afrikaanse filmbedryf as die regisseur van Abraham (Rautenbach se vorige film was Broer Matie in 1984). Rautenbach en Roets se vennootskap wat reeds samewerking aan vier films sedert Roets se debuut as kamera-assistent by Kimberley Jim ingesluit het, word hervat en Roets tree as kinematograaf op.

'n Pawpaw vir my darling (2016) is volgens Van Nierop (2016:376) 'een van die beste en dapperste rolprente van sy roemryke loopbaan'. Soos met Kootjie Emmer, Siener en die suburbs, Nag van die negentiende, Paljas en Die wonderwerker span Roets hier weereens saam met 'n bekende Afrikaanse skrywer, in hierdie geval Jeanne Goosen, op wie se boek die film gebaseer is. Die rolverdeling sluit 'n groot hoeveelheid van die bekendste akteurs in die Afrikaanse filmbedryf in wat Pople (2015) 'n 'konstellasie van sterre' noem, naamlik André Stoltz, Brümilda van Rensburg, Dawid Minnaar, Deon Lotz, Helene Truter, Lida Botha, Marcel van Heerden, Marga van Rooy, Martelize Kolver, Sandra Prinsloo, Tobie Cronjé en Willie Esterhuizen. Vele van hierdie akteurs het in die verlede gereeld saam met Roets gewerk en verteenwoordig sommige van die toonaangewende akteurs in die hedendaagse Afrikaanse filmbedryf.

Bogenoemde is maar enkele voorbeelde van mense saam met wie Roets gereeld gewerk het. Ander persone wat ook vlugtig genoem kan word, sluit in Con Lamprecht (Danie Bosman, Die geheim van Nantes en Lied in my hart), Regardt van den Bergh (Eendag op 'n reëndag, Lag met Wena en Paljas), Sandra Kotze (Jannie totsiens, Die wonderwerker en Faan se trein), Trix Pienaar (Pappalap, Kootjie Emmer en Die groen faktor), Tromp Terre'Blanche (Lord Oom Piet, Kimberley Jim, Pikkie en More, more), André Scholtz (Die wonderwerker en 'n Pawpaw vir my darling), André Stolz (Wie laaste lag en 'n Pawpaw vir my darling), Anna Neethling-Pohl (More, more en Dit was aand en dit was more), Deon Lotz (Faan se trein en 'n Pawpaw vir my darling), Dirk de Villiers (Die geheim van Nantes en Kaalgat tussen die daisies), Frank Opperman (Wie laaste lag en Kaalgat tussen die daisies), Gys de Villiers (Kaalgat tussen die daisies en Paljas), Lida Botha (Wie laaste lag en ' $n$ Pawpaw vir my darling), Marcel van Heerden (Nag van die negentiende en ' $n$ Pawpaw vir my darling) en Zack du Plessis (Springbok en Kaalgat tussen die daisies).

Deur sy loopbaan het Roets met ander woorde gereeld saam met 'n klein aantal mense gewerk, alhoewel hy in die geheel saam met meer as 'n 1000 mense tot Afrikaanse films bygedra het. Omdat daar so baie mense is wat saam met hom gewerk het, kan sy totale samewerkingsnetwerk nie in 'n enkele artikel bespreek word nie. Wat egter duidelik uit die bostaande inligting is, is dat dit nie slegs mense is wat sleutelrolle in die Afrikaanse filmbedryf gespeel het en steeds speel nie, maar veral dat Roets saam met van die belangrikste mense wat die Afrikaanse filmbedryf tot stand gebring het én diegene wat dit tans in stand hou, gewerk het. Dít onderskei sy rol in die Afrikaanse filmbedryf van iemand soos byvoorbeeld Pierre de Wet wat gereeld as die vader van die Afrikaanse filmbedryf bestempel word. Roets was nie die vader van die filmbedryf nie, maar hy was 'n belangrike skakel tussen die mense wat verantwoordelik was vir die ontstaan van die Afrikaanse filmbedryf sowel as diegene wat tans vir die instandhouding hiervan verantwoordelik is.

\section{Gevolgtrekking}

Wanneer 'n mens die geskiedenis van die Afrikaanse filmbedryf opteken, is dit nie alleen mense se individuele bydraes wat van belang is nie, maar ook hoe hulle met mekaar saamgewerk het. Die filmbedryf is by uitstek 'n bedryf waarin mense se samewerking tot die eindproduk lei: films is nie die skepping van 'n enkele persoon nie, maar eerder die produk van verskeie rolspelers se samewerking. Die huidige artikel het hierdie feit juis beklemtoon deur Koos Roets se samewerkingsverhoudings te ondersoek. Deur sy loopbaan het Koos Roets saam met meer as 'n 1000 mense (volgens die krediete van films waarby hy betrokke was) gewerk, onder andere saam met van die belangrikste rolspelers in die Afrikaanse filmbedryf soos Pierre de Wet, Emil Nofal, Jamie Uys, Jans Rautenbach en Katinka Heyns. Hierdie artikel het sy samewerkingsnetwerk oor dekades heen verken deur ondersoek in te stel na persone, spesifiek die regisseurs en akteurs, met wie hy die meeste saamgewerk het. Daar is uitgelig dat hy veral gereeld saam met Sias Odendaal, Katinka Heyns, Tobie Cronjé, Jans Rautenbach en Franz Marx gewerk het, en hierdie samewerkingsverhoudings is in meer detail bespreek deur na individuele films en sy samewerkingsnetwerk met verloop van tyd te kyk. 'n Belangrike bevinding is dat die samewerkingsnetwerk wat hy met verloop van tyd gebou het, hom in kontak gebring het met mense uit verskillende generasies soos dit in hierdie artikel uitgelig is. Dit onderskei hom van rolspelers soos Pierre de Wet wat tot 'n ouer generasie behoort, of Willie Esterhuizen wat tot 'n nuwer generasie behoort. Die spesifieke aard van hierdie samewerkingsverhoudings, byvoorbeeld watter tegnici en regisseurs Roets as rolmodelle geag het en in watter opsig hulle 'n invloed op hom uitgeoefen het, kan in 'n kwalitatiewe studie verder ondersoek word.

'n Interessante faset van Koos Roets se samewerkingsnetwerk wat in die huidige artikel na vore gekom het, is die hoeveelheid kere wat hy saam met gevestigde Afrikaanse skrywers soos André P. Brink, Pieter Fourie, P.G. du Plessis, Chris Barnard, Verna Vels en Jeanne Goosen gewerk het. Benewens Roets se belangrike rol in die Afrikaanse filmbedryf as aanknopingspunt tussen generasies, sou sy verbindingsrol tussen die Afrikaanse letterkunde en die filmbedryf ook nagevors kon word - iets wat in 'n toekomstige studie onderneem sou kon word. Studies soos dié van Kleyn (2013) 
het juis binne 'n sisteemteoretiese raamwerk ondersoek ingestel na die skakel tussen die Afrikaanse letterkunde en die film. Senekal (1987) merk op hoe vloeiend die grense tussen hierdie twee mediums soms kan wees:

Ofskoon film, radio, blitsverkoper en reportage die 'heilige drieeenheid' epiek, liriek en dramatiek reeds sedert die twintigerjare onseker laat lyk, het die tegniek eers na 1945 so ver gevorder dat dit onmoontlik geword het om nog van duidelik herkenbare soorte en genres te praat. In die laaste desennia kom daar 'n mediaverbond tot stand: uit romans word films gemaak, uit kort verhale hoorspele, uit films teaterstukke, uit hoorspele romans. Daar is geen grense aan hierdie beweging tussen verskillende media en genres nie. (bl. 7)

Roets se rol binne die Afrikaanse kultuurbedryf skakel juis in by hierdie oorgrensfunksionering van mense en werke. 'n Mens sou ook Roets se rol as brugbouer tussen televisie en film kon ondersoek, waar Roets byvoorbeeld reekse soos Laat vrugte geregisseer het.

\section{Erkenning Mededingende belange}

Die outeurs verklaar dat hulle geen finansiële of persoonlike verbintenis met enige party wat hulle nadelig of voordelig kon beïnvloed het in die skryf van hierdie artikel nie.

\section{Outeursbydrae}

C.G. het die data ingesamel, B.A.S. het die date geanaliseer. Die artikel in sy geheel is gesamentlik geskryf deur C.G. en B.A.S.

\section{Literatuurverwysings}

Allen, M.P. \& Lincoln, A.E., 2004, 'Critical discourse and the cultural consecration of American films', Social Forces 82(3), 871-894. https://doi.org/10.1353/sof.2004.0030

Barabási, A.-L., Albert, R. \& Jeong, H., 1999, 'Mean-field theory for scale-free random networks', Physica A 272, 173-187. https://doi.org/10.1016/\$0378-4371(99)00291-5

Baumann, S., 2001, 'Intellectualization and art world development: Film in the United States', American Sociological Review 66(3), 404-426. https://doi.org/10.2307/ 3088886

Baumann, S., 2002, 'Marketing, cultural hierarchy, and the relevance of critics: Film in the United States, 1935-1980', Poetics 30, 243-262. https://doi.org/10.1016/ S0304-422X(02)00023-2

Botha, M., 2006, Jans Rautenbach: Dromer baanbreker en auteur, Genugtig, Melkbosstrand.

Botha, M., 2015, The cinema of Katinka Heyns, Kinema, Lente, viewed 22 December 2017, from http://www.kinema.uwaterloo.ca/article.php?id=575\&feature

Botha, M., 2016, Jans Rautenbach: Dromer en baanbreker, besoek 11 November 2016 by http://www.netwerk24.com/Stemme/Aktueel/jans-rautenbach-dromer-enbaanbreker-20161103

Botha, M. \& Van Aswegen, A., 1991, 'Suid-Afrikaanse "alternatiewe" rolprente en die Suid-Afrikaanse sosio-politieke werklikheid. ' $n$ Historiese, teoretiese en analitiese verkenning (Deel 1)', Communicatio 17(1), 72-91. https://doi.org/10.1080/ 02500169108537866

Bourdieu, P., 1971, 'Intellectual field and creative project', in M. Young (red.), Knowledge and control: New directions for the sociology of education, pp. 161-188, Collie Macmillan, London.

Bourdieu, P., 1983, 'The field of cultural production, or: The economic world revisited' Poetics 12, 311-356. https://doi.org/10.1016/0304-422X(83)90012-8

Costa, L.D.F., Oliveira, O.N., Travieso, G., Rodrigues, F.A., Villas Boas, P.R., Antiqueira, L. et al., 2011. 'Analyzing and modeling real-world phenomena with complex networks: A survey of applications', Advances in Physics 60(3), 329-412. https:// doi.org/10.1080/00018732.2011.572452

Davis, G.F., Yoo, M. \& Baker, W.E., 2003, 'The small world of the American corporate elite, 1982-2001', Strategic organization 1(3), 301-326. https://doi.org/10.1177/ 14761270030013002

De Swardt, C.J., 2017, Koos Roets, 'n onderhoud, besoek 10 Februarie 2017, by http://www.litnet.co.za/koos-roets-n-onderhoud/
DiMaggio, P., 1979, 'On Pierre Bourdieu', American Journal of Sociology 84(6), 14601474. https://doi.org/10.1086/226948

Ding, Y., 2011, 'Scientific collaboration and endorsement: Network analysis of coauthorship and citation networks', Journal of Informetrics 5(1), 187-203. https://doi.org/10.1016/j.joi.2010.10.008

Fruchterman, T.M. \& Reingold, E.M., 1991, 'Graph drawing by force-directed placement' Software: Practice and experience 21(11), 1129-1164. https://doi.org/10.1002/ spe.4380211102

Gallos, L.K., Potiguar, F.Q., Andrade, J.S. \& Makse, H.A., 2013, 'Imdb network revisited: Unveiling fractal and modular properties from a typical small-world network', PloS one 8(6), e66443. https://doi.org/10.1371/journal.pone.0066443

Giannetti, F., 2016, 'A review of network approaches in music studies', Music Reference Services Quarterly 19(2), 156-163. https://doi.org/10.1080/10588167.2016.1166842

Guillaume, J.-L. \& Latapy, M., 2004, 'Bipartite structure of all complex networks', Information Processing Letters 90, 215-221. https://doi.org/10.1016/j.jpl.2004.03.007

Guimera, R., Uzzi, B., Spiro, J. \& Amaral, L.A.N., 2005, 'Team assembly mechanisms determine collaboration network structure and team performance', Science 308 697-702. https://doi.org/10.1126/science.1106340

Heise, T. \& Tudor, A., 2007, 'Constructing (film) art: Bourdieu's field model in a comparative context', Cultural Sociology 1(2), 165-187. https://doi.org/10.1177/ 1749975507078186

Jacobs, E.M., 2016, Die posisie van swart skrywers van Afrikaanse prosa in die Afrikaanse prosasisteem sedert 1992, Ongepubliseerde PhD-proefskrif, Universiteit van Pretoria.

Jansen van Vuuren, A.-M., 2016, Jans Rautenbach, filmmaker, op tagtig, besoek 31 Oktober 2016, by http://www.litnet.co.za/jans-rautenbach-filmmaker-op-tagtig/

Kleyn, L., 2013, 'n Sisteemteoretiese kartering van die Afrikaanse literatuur vir die tydperk 2000-2009: Kanonisering in die Afrikaanse literatuur, Ongepubliseerde PhD-proefskrif, Universiteit van Pretoria.

Lewin, K., 1939, 'Field theory and experiment in social psychology: Concepts and methods', American Journal of Sociology 44(6), 868-896. https://doi.org/10.1086/ 218177

Lombaard, L., 2014, Faan se trein, besoek 7 November 2016, by http://www.perdeby. co.za/ sections/entertainment/3422-faan-se-trein-director-koos-roets

Manuel, D.G., Lam, K., Maaten, S. \& Klein-Geltink, J., 2011, 'Using administrative data to measure the extent to which practitioners work together: "interconnected" care is common in a large cohort of family physicians', Open Medicine 5(4), 177-182.

Marx, L., 2014, “'How much does anyone need to know about Eugène Marais?" The Guest and Die Wonderwerker', South African Theatre Journal 27(3), 247-264. https://doi.org/10.1080/10137548.2014.968463

Nel, A., 2003, 'Stagnering en transformering: Die rol van die nar in Paljas', Literator 24(2), 1-18. https://doi.org/10.4102/lit.v24i2.288

Phalen, F., Ksiazek, T.B. \& Garber, J.B., 2016, 'Who you know in Hollywood: A network analysis of television writers', Journal of Broadcasting \& Electronic Media 60(1), 160-170. https://doi.org/10.1080/08838151.2015.1127244

Pople, L., 2015, 'Konstellasie van sterre' in Roetsfliek, Maar Tsjaka die hond het as verteller die meeste sê', Volksblad, 27 Augustus. https://www.pressreader.com/ verth-africa/volksblad/20150827/281831462486918

Pople, L., 2016, Pawpaw vir my Darling' kruip gou in jou hart in, besoek 11 November 2016, by http://www.netwerk24.com/Vermaak/Flieks/flieks-pawpaw-vir-mydarling-kruip-gou-in-jou-hart-in-20160107

Prell, C., 2012, Social network analysis. History, theory and methodology, Sage, London.

Senekal, B.A., 2014a, 'An investigation of Pierre de Wet's role in the Afrikaans film industry using Social Network Analysis (SNA)', Literator 35(1). http://dx.doi. org/10.4102/lit.v35i1.1099

Senekal, B.A., 2014b, 'Olga Kirsch se posisie in die Afrikaanse literêre sisteem (19001978)', Werkwinkel 9(2), 9-36. https://doi.org/10.2478/werk-2014-0015

Senekal, B.A., 2015a, 'Die kwantifisering en toepassing van modulariteit in die Afrikaanse filmbedryf (1994-2014) as 'n komplekse netwerk', Suid-Afrikaanse Tydskrif vir Natuurwetenskappe en Tegnologie 34(1). https://doi.org/10.4102/ satnt.v34i1.1305

Senekal, B.A., 2015b, "n Veelvlakkige netwerkontleding van die Afrikaanse filmbedryf (1994-2014)', LitNet Akademies (Geesteswetenskappe) 12(2), 43-68.

Senekal, B.A. \& Stemmet, J.-A., 2014, 'The gods must be connected: An investigation of Jamie Uys's connections in the Afrikaans film industry using Social Network Analysis (SNA)', Communicatio 40(1), 1-19. https://doi.org/10.1080/02500167.20 14.888361

Senekal, J.H., 1987, Literatuuropvattings: 'wese' en 'waarhede' van 'n nuwe literêre teorie, Universiteit van die Oranje-Vrystaat, Bloemfontein.

Stemmet, J.-A., 2015, 'Sangoma of the silver screen: Jamie Uys as film maker 19501964', Ensovoort.

Van Nierop, L., 1999, 'Lewende legendes - Katinka Heyns', Beeld, 17 Desember, p. 3.

Van Nierop, L., 2016, Daar doer in die fliek, Protea Boekhuis, Pretoria.

Van Staden, C., 2016, 'Ontleding van sosiogramme as metode om die doeltreffendheid van genetwerkte leer in 'n skoolgebaseerde wiskundevakgroep te ondersoek', LitNet Akademies Opvoedkunde 13(3), 672-718.

Watts, D.J. \& Strogatz, S.H., 1998, 'Collective dynamics of 'small-world' networks', Nature 393(6684), 409-410. https://doi.org/10.1038/30918

Zhang, P.-P., Chen, K., He, Y., Zhou, T., Su, B-B., Jin, Y. et al., 2006, 'Model and empirical study on some collaboration networks', Physica A 360, 599-616. https://doi. org/10.1016/j.physa.2005.05.044 